\title{
Economic Impact of Cruise Activity: The Case of Barcelona
}

\section{Esther Vayá, José R. Garcia, Joaquín Murillo, Javier Romaní \& Jordi Suriñach}

AQR Research Group-Research Institute of Applied Economics, University of Barcelona, Avda Diagonal, 690, Barcelona, 08034, Spain

\section{Abstract}

This article shows the methodology and the main figures of the local and regional economic impact generated by cruise activity. This article is pioneering in combining different issues: estimating the impact of the cruise port activity, presenting these impacts disaggregated at a sectoral level, using a rigorous methodology and carrying out extensive fieldwork. It is demonstrated that all sectors, not just traditional tourism-related sectors, benefit from cruise tourism. In order to test and apply our methodology we focus the analysis in The Port of Barcelona, which has become the leading cruise port in the Mediterranean area.

Keywords: Cruise Tourism, Economic Impact, Catalyst Effects, Input-Output Methodology, Port of Barcelona. 


\section{Introduction}

The economic importance of tourism is widely acknowledged. Despite its maturity, the tourism sector is a highly dynamic one, as the exponential boom in cruise tourism in recent years show. The World Tourism Organization (2008) has reported that global demand for cruises has grown over the last twenty years, at a cumulative annual rate of 8\%. In turn, the Cruise Lines International Association, CLIA (2015), points out that in the last ten years, despite the economic crisis, global demand for cruises has increased by $84 \%$, from 13.1 million passengers in 2004, to 22.04 in 2014 .

This growth and dynamism has increased the number of countries which think of cruises as a key product for tourism development. Although the Caribbean was the main destination of cruise tourism worldwide in the 1970s, the following years witnessed the rise of very successful alternative destinations, located in the Gulf of Mexico, the Atlantic, the Pacific, northern Europe and especially, in the Mediterranean basin (who nowadays accounts for almost $20 \%$ of the global cruise market, being the second most popular cruise destination behind the Caribbean). The cruise industry has thus become an engine of economic acceleration for many local economies in the Mediterranean (Papadopoulou and Sambracos, 2014). Western Mediterranean ports stand out for both the number of cruise passengers and number of cruise calls $(67 \%$ and $57 \%$ respectively in 2012; MedCruise Yearbook, 2013 / 2014), and the Port of Barcelona is leading cruise port in the Mediterranean area.

Despite the importance that cruise tourism has acquired in recent years, there are still few studies that attempt to quantify its economic impact. Those few include the worldwide economic impact estimates that are conducted periodically by the 
International Association of Cruise Lines, who estimated the global economic contribution of the cruise industry in 2014 as 112.7 million euros, with 939,232 fulltime jobs. The share of the European cruise industry would have been 40.2 million euros and 350,000 jobs (CLIA, 2015). These reports however, do not show any territorial disaggregation below country level. The European Commission has also tried to estimate the economic impact of cruises, although final results are aggregated for all European ports (Policy Research Corporation, 2009). At a more disaggregated level, there are the impact studies of Braun et al. (2002) for Port Canaveral in Florida; Chase and Alon (2002) for Barbados; Gibson and Bentley (2006) for England; the impact study for Mexico prepared by the Business Research and Economic Advisors (BREA, 2007); Brida and Zapata (2010a) in the case of Costa Rica; Papadopoulou and Sambracos (2014) for Greek ports or the study of CERTeT Bocconi (2015) for the port of Civitavecchia. In spite of these works, the number of studies that estimate in detail the economic impact of cruise tourism at regional or local level remains very low. In an attempt to close the gap, this article is pioneering at European level for its rigorous methodology and comprehensive fieldwork. We have gone a step beyond other preexisting studies. Thus, we have estimated the disaggregated impacts at the sectoral level, we have considered the three main groups involved (cruisers, shipping companies and consignees, and crew), also we have included all existing impacts (direct, indirect and induced), the methodology used has been explained in detail and the results have been relativized to the usual macromagnitudes, such as gross domestic product, total employment and tax revenues.

In order to test and apply our methodology, we have quantified the regional economic impact of cruise tourism in the leading Mediterranean port, the Port of Barcelona 
(located in the city of Barcelona and within the European region of Catalonia). Using input-output (I-O) methodology, the overall impact of cruise tourism is calculated for the year 2014 as the sum of three partial impacts: direct, indirect and induced. To estimate the direct impact we have conducted extensive fieldwork, gathering information about spending by shipping companies, cruise passengers and the ships' crews. The computation of indirect and induced impacts has been made using information from the latest regional Input-Output Table available for Catalonia (Idescat, 2011). This impact is quantified in terms of its effect on the gross domestic product (GDP), employment and tax revenues generated (regional and state tax and tourist tax). Since the impact generated by cruise activity extends beyond the purely economic sphere, we also carry out a brief analysis of its social and environmental effects. The article is structured as follows. Section 2 presents the literature review and methodology used for calculating the impact of cruise activity, and Section 3 describes the data sources used and briefly describes the dimension of cruise activity at the Port of Barcelona. In Section 4 the results of the estimation of the economic impact are shown. Section 5 briefly discusses additional effects of cruise activity. Finally, conclusions and implications are presented in Section 6. 


\section{Literature review and methodology}

For the analysis of the economic impact of one activity, the literature proposes different alternative methodologies. Among them, the most common are the one based on the use of the Input Output (I-O) tables and the General Equilibrium models (GEM). There is some consensus on preferring the second methodology as preferable to the first one (Dwyer et al., 2006; Dwyer et al., 2008; Forsyth et al., 2014), because it is more complete. It analyzes short and long term effects, considering the impact dynamically, over time. However the I-O methodology is also widely used (Fletcher, 1989; Wagner, 1997, Del Corpo et al, 2008; Heng and Low, 1990; Murillo et al, 2008) and defended (Dwyer and Forsyth, 1998, Dwyer et al, 2003a, 2003b, among others) and has the advantage that it allows to take into account all the cross-sector multiplier effects (and it details the impact for all economic sectors).

Other arguments that justify the use of the IO methodology are: (a) Dwyer, Forsyth and Spurr (2004) recognize that in "small regional economies or sub-state regions" (like our case study), there are no large differences between the two type of models. In addition, in the GEM there is the difficulty of modeling all the relationships between economic variables in a small area. (b) In addition, GEM requires the provision of statistical information of many economic variables at municipal level, difficult to achieve in small areas. (c) Additionally, other articles (Zhou et al, 1997) that have used the two approaches in the same area, have obtained very similar results in both. (d) Finally, the main criticism of the I-O model is that it is a model of constant technical coefficients, constant returns to scale, and it does not consider the potential variation of prices in the inputs: the changes in prices in the factors generate changes of investment, and labor 
costs that affect the whole economy. However, in the Spanish case, with high

unemployment rates, there are resources that allow one sector to use more without having to be deprived of the rest of the sectors. Therefore, considering all previous facts, in order to quantify the economic impact of cruise activity, we have followed the I-O methodology used ${ }^{1}$ in other impact studies based on the quantification of three types of effects: direct impact, indirect impact and induced impact (Murillo et al., 2008; Murillo et al., 2013). For our purposes, the direct impact consists of the sum of initial spending by the three agents involved in cruise activity: shipping companies, cruise passengers and crew. The initial direct spending generated by shipping companies includes all goods and services needed when cruise ships dock at a port. The following expenses are included: services provided by shipping agents, services provided by the cruise terminals (luggage, safety, handling, check-in, etc.); services provided by the port (including taxes and port fees); nautical pilotage and the mooring and unmooring of ships -technical services waste collection and treatment; fuel supply services; food, beverages and drinking water (among other provisions); crew trips and airport charges; medical care for both crew and passengers; and services provided by travel agencies and tour operators.

The initial direct spending by cruise passengers includes spending on trips, visits to museums and other cultural and entertainment activities; accommodation ${ }^{2}$ (hotels, hostels and tourist apartments); expenses (restaurants and cafes); various purchases (souvenirs, clothing and footwear, etc.); the city internal transport (including transfers from the airport/train station to the port and vice versa) and airport charges. Finally,

\footnotetext{
${ }^{1}$ See Miller and Blair (2009) for a more detailed description of the I-O methodology. The authors offer to complement information to readers, if it is required.

${ }^{2}$ There are passengers who spend one or more nights in Barcelona before boarding or after disembarking.
} 
direct spending by the crew in the city includes: expenses (restaurants and cafes); various purchases (souvenirs, clothing and footwear, etc.); and internal transport around the city.

The indirect impact is the effect on other sectors of the economy, generated as a result of the goods and services required by the companies that are receiving direct expenditure. For example, for a hotel to accommodate a cruise passenger, it also needs to purchase a set of goods (such as textiles, food products, etc.) and services (cleaning, transportation, etc.). Similarly, companies mooring, and pilot boat, require a range of goods and services to carry out their activity in port based on the cruise companies. In turn, these "second order" providers require goods and services for the development of their activity and so on. Thanks to the impact of the spending by shipping companies, cruise passengers and crew, production in all sectors is increased, thereby generating a multiplier effect throughout all economic sectors. This intersectoral impacts have been computed based on I-O table. In order to consider all direct expenditures, all of them have been linked to the 82 branches considered in I-O tables, and based on multiplier effects of I-O table, the intersectoral effects are computed.

The induced impact is the effect derived from consumer spending of revenue generated employment (directly and indirectly) in cruise activities. People who occupy these jobs owe them directly or indirectly, to cruise activity in the port. These people receive a wage income that will be allocated in part (after deducting taxes, contributions and savings) to consuming goods and services in their place of residence/work. This thus reactivates a chain of intersectoral relationships that lead to an increase in the turnover of different economic sectors. 
In order to estimate the total impact of activity, each of the three types of impact (direct, indirect and induced) have been quantified separately, with subsequent aggregation. 


\section{Information Sources. The case of Barcelona.}

We are using the case of the Port of Barcelona for a practical application of our methodology, so we will briefly review the main facts related cruise tourism in this port and its importance for the economy of the city of Barcelona and the whole region of Catalonia.

Compared with other European ports (Table 1), the Port of Barcelona stood just behind the port of Civitavecchia in transit passengers, with a figure of 1,141,804 passengers and just behind the ports of Venice and Southampton in boarding and disembarking, with 1,222,488 passengers. The Port of Barcelona thus has relevance not only as a port of call but also as a home port, where boarding and disembarkation account for $52 \%$ of the total movement of cruise passengers in 2014. As will be seen later the port of Barcelona as a homeport, is very significant for the purposes of economic impact, as the revenue generated by passengers boarding/disembarking is larger than that from transit passengers.

[Table 1 near here]

Analyzing the evolution of cruise activity in the Port of Barcelona, we can see an important growth in the number of cruise passengers since the 1990s, and especially since 2001. Despite the economic crisis, the number of cruise passengers grew between 2007 and 2011 at an average annual rate of $10.8 \%$, from 1,765,838 cruise passengers in 2007 to 2,657,244 in 2011. Since 2011 the trend has been more stable (Figure 1).

[Figure 1 near here]

Authors such as Garay and Cànoves (2012) claim that the preparation of Barcelona for the 1992 Olympic Games marked a turning point, from holding a marginal position in 
the cruise tourism segment to the current leadership position. Many contributing factors, according to these authors, explain this leadership. The strategic geographical position of the city and excellent port infrastructure can both be highlighted. The quality of logistics services in the port area, the continuous investments made to adapt the terminals and allow the berthing of very large vessels, and the security offered by the city compared to other tourist destinations in the Mediterranean should also be noted. Finally, the city of Barcelona is attractive in terms of architectural and cultural heritage in general, and in dining and shopping and entertainment.

In order to estimate the direct impact of cruises, we performed very thorough and rigorous field-based research with the use of multiple primary and secondary sources of information.

\section{i) Initial direct spending by shipping companies}

To estimate the initial direct spending by shipping companies in 2014 , we collected direct information provided by the suppliers of goods and services to these companies, along with additional information from other complementary sources. We obtained direct information provided by the Shipping Agents of Barcelona Port Terminals Cruise Port, the Port Authority of Barcelona (APB), companies for technical-nautical pilotage and the mooring of vessels, and collection and waste treatment companies. These companies answered questionnaires, providing the following information: activity data of the company (turnover, number of employees, generated GVA broken down by component, and tax revenues); expenditure data from external suppliers of the company (intermediate consumption disaggregated by the geographical location of their providers), and total amounts billed to different cruise ship companies operating in the 
Port of Barcelona (broken down by concept). An estimate was made of direct spending by shipping companies on services provided by the cruise terminals (luggage, safety, handling, check-in, etc.); services provided by the Port Authority of Barcelona (fees for the maritime signaling, use of port facilities for berthing ships and passenger reception); services provided by the consignees of ships; waste collection and treatment services; technical-nautical services (mooring/unmooring and pilotage of ships); crew trips and airport charges; and medical care for both crew and passengers. ${ }^{3}$

Quantification was performed considering customs information about provisions for all types of vessels (both in tons and direct monetary expenditure by the cruise companies), value based on geographical origin (foreign and domestic) and the type of product, such as information provided by the Barcelona Port Authority on tons of provisions charged to cruise ships. Only supplies manufactured in Catalonia were included in our estimations.

We collected information about supply services and fuel purchases. The calculation of fuel expenditure was obtained by applying the volume of refueling by fuel types Gasoil, Fuel and Fuel Light 3.5\% - to Platts Prices Index prepared by Mc Graw Hill Financial for December 2014. We allocated to Spain and Catalonia only the proportion of the fuel refined in Spanish and Catalan facilities, with respect to the total amount of these expenses. Fuel imported from other countries has not been considered for the purposes of the study on the grounds that, as well as purchase transactions, an added value from refining activities has been generated in the countries of origin.

\footnotetext{
3 Six of the eight consigning companies have been submitted information. For the remaining two, the required data have been estimated based on the information on the cruise passengers managed by each one. Likewise, the two mooring companies operating in the port have collaborated in the study, although it has been necessary to estimate the percentage of their total activity that is linked only to the cruise activity (this estimate was made following the instructions of Barcelona Port Authority).
} 
Finally, we estimated the services performed by the travel agents and tour operators who organize the trips and excursions for cruise passengers. We approximated the value of such services from the information provided by both CLIA-Spain (Association of Cruise Companies) and the Survey of Cruisers 2014 (discussed in detail below) for the percentage of cruise passengers in the Port of Barcelona compared to residents in Catalonia who also book the same excursions.

ii) Initial direct spending by cruise passengers

Both the magnitude of daily spending by cruise passengers and its structure have been identified via an analysis of the microdata from the Survey of Cruisers 2014 (Barcelona Tourism, 2015), a survey based on a representative sample of 3,130 cruise passengers who started their cruise, completed it or simply stopped in the port of Barcelona ${ }^{4}$.

iii) Initial direct expenditure made by the crew

We contacted the Port of Barcelona, who provided us with information about the name of the cruise ships that docked at the Port of Barcelona (and stopover) in 2014, and the technical specifications of these ships (which include, among other information, the number of crew members). To estimate the initial spending of the crew, we used information from the Port Authority of Barcelona and CLIA-Spain (Association of Companies Cruise) in relation to both the percentage of crew disembarking to visit the city and their average expenditure. For the distribution of this expense among detailed items, we used the "Tourist Facilities in Ports" study by the Policy Research Corporation (2009).

\footnotetext{
4 "Barcelona Tourism" did between March-December 2014, 3130 interviews to cruise passengers of 16 or older, who start or end a cruise, or who are on the stairs, at the Cruise Terminals of the Port of Barcelona. Sampling type: Quotas by type of cruiser depending on the type of scale (boarding, disembarkation and transit). Type of interview: Personal computer assisted interview, CAPI system.
} 


\section{Estimation of the economic impact of cruise activity}

We present the results of the impact of activity in the Cruise Port of Barcelona, as both the total impact and as divided into direct, indirect and induced impact.

\subsection{Estimated direct impact of cruise activity}

Estimation of the direct impact involved analyzing the separate effect of the three generating agents identified: shipping companies, cruise passengers and crew members.

i) Estimated direct expenditure of shipping companies

We estimate from all the fieldwork that the direct spending of cruise shipping companies in Catalonia, in 2014 was 121.2 million $€(M €)$. As shown in Figure 2, procurement services and fuel supply accounted for $30.2 \%$ of the direct expenditure by shipping companies. The reason for this large proportion is that cruise companies use the Port of Barcelona as one of the main ports in the Mediterranean for refueling and procuring supplies. As a main base port, Barcelona also has dedicated terminals for the reception, storage and distribution of fuel and gas. In decreasing order of importance, this includes spending on provisions (19.2\%) and the services provided by the terminals (18.8\%), followed by the services of travel agencies and tour operators (11.3\%) and services of the Port Authority (8.0\%). Other items are a lesser proportion of the total spending.

[Figure 2 near here]

It is important to note that this amount includes only the portion of spending that directly reverts to the Catalan economy and constitutes an "initial injection of money" in Catalonia. This amount does not include all spending by the cruise companies who docked at the Port of Barcelona in 2014. The following items should thus be added to 
this amount: tourist tax paid by shipping companies for cruise passengers in transit who remain in the city for more than 12 hours; payments made for provisions from the rest of Spain; payments for services rendered by travel agencies and tour operators from the rest of Spain and abroad (related to the sale of the cruise package and/or tours taken by cruise passengers who board, disembark or simply visit the Port of Barcelona); and payments for fuel from other facilities in the rest of Spain.

ii) Estimated direct expenditure of cruise passengers

We used the data about cruise passenger flows from the Port of Barcelona and the survey of cruise passengers to obtain a typology of cruise passengers. As shown in Table $2,57.5 \%$ of cruise passengers made a visit to the city of Barcelona (with an average duration of 4.3 hours), without an overnight stay. Within this group we can distinguish transit cruise passengers (cruise passengers off the boat only for a few hours while the cruise makes a stopover, whose average duration of visit to the city was 4.2 hours) and cruise passengers for whom Barcelona is the start/end port and who paid a visit to the city before and/or after boarding or disembarking (mean duration 4.7 hours). In contrast, almost $24 \%$ of cruise passengers were tourists in Barcelona, as they stayed at least one night in the city (average stay of 2.6 nights). $94.2 \%$ stayed in hotels (with 3.9 stars average). This percentage compares favorably with the $40 \%$ of holiday tourists who stayed in hotels (data collected from the Survey Tourists, Barcelona City Council, 2015). Finally, only $18.6 \%$ did not make any visit to the city before or after boarding or disembarking (most were Barcelona residents).

[Table 2 near here] 
Cruise passengers who also stayed overnight made a daily expenditure per person of $200 €$ (holiday tourists averaged $156.4 €$ daily, according to the Tourists Barcelona survey). On the other hand, the average daily expenditure of a "day visitor" cruise passenger (visited the city without spending the night) was $53.3 €$. This difference in spending demonstrates the importance of Barcelona as a home port rather than a port of call. This is because cruise passengers boarding and/or disembarking have additional expenditure (with respect to cruise passengers in transit) in terms of the use of air links, rail or road transport to get to their destination, as well as increased spending during the pre- and post-cruise: accommodation, catering and consumption of complementary offers.

Once we know the average daily spending for all categories of cruise passengers, their average stay in the city, and the quantification of the flow of cruise passengers in the city, we can proceed to the calculation of the direct impact generated by cruise passengers in the city. It has thus been estimated that their total direct expenditure amounted to $315.8 \mathrm{M} €$. This amount includes expenditure incurred by both passengers who just visited the city and passengers boarding and/or disembarking at the start or end of their cruise at the Port of Barcelona. In terms of distribution by concepts (see Figure 3), expenditure on accommodation and catering (food and beverages) accounted for almost $58 \%$ of all spending by cruise passengers, followed at a greater distance by expenses in various shopping categories (15.4\%), transport (15.5\%) and excursions $(11.4 \%)$

[Figure 3 near here] 
iii) Estimated direct expenditure by crew members

Using all the information consulted (described in Section 3), we estimate that 660,863 cruise ship crew members docked at the port: 428,462 belonged to ships that used Barcelona as a port of call, while the remaining 232,401 worked on ships that had Barcelona as their homeport (beginning and end of the line). The distinction between a port of call and homeport is relevant because, as directed by CLIA-Spain, we have assumed that the proportion of crewmembers that visited the city was $40 \%$ of the crew when the Port of Barcelona was a port of call and $25 \%$ when it was a homeport (these assumptions have been made following the indications of CLIA-Spain and the Barcelona Port Authority).

It has also been estimated that the crewmembers visiting the city made an average expenditure of $25 €$ (following the information provided by CLIA-Spain), distributed as follows ${ }^{5}$ : 50\% shopping, $40 \%$ restaurants and bars, and 10\% internal transports (Figure 4). We have thus finally estimated that the initial spending by crew reached $5.5 \mathrm{M} €$, directly generating a GVA of 3.3 $\mathrm{M} €(1.7 \mathrm{M} €$ of wage income $)$ and 76 jobs.

[Figure 4 near here]

iv) Estimated total direct spending

We finally estimate that the initial direct spending in Catalonia by the three agents involved totaled $442.5 \mathrm{M} €$. Spending by cruise passengers accounted for $71.4 \%$ of the total initial spending, and the spending of shipping companies accounted for $27.4 \%$ and of crew, $1.2 \%$ (Figure 5).

[Figure 5 near here]

\footnotetext{
${ }^{5}$ This distribution has been made following the estimations of Policy Research Corporation (2009).
} 
From these results, and using information from the Regional Accounts of Catalonia and the Input-Output Table of Catalonia (2011), it has been estimated that the initial expenditure of $442.5 \mathrm{M} €$ meant a GVA of $225.9 \mathrm{M} €$ (direct contribution to GDP of Catalonia) for the Catalan economy, of which 116.7 $\mathrm{M} €$ were wages and related costs (52\%). Finally, it has been estimated that cruise activity in the Port of Barcelona generated 4,026 direct full-time equivalent jobs.

The sectoral distribution of direct impact is characterized by a remarkable concentration in a few sectors. In terms, for example, of occupation (Figure 6), 87\% of all direct jobs generated by cruise activity is concentrated in five of the eighty-two sectors considered: hosting services, retail, services catering, ground transportation and leisure activities (sectors traditionally related to tourism).

[Figure 6 near here]

4.2. Estimation of the indirect and induced impacts of cruise activity

From that initial impact a number of complex intersectoral relationships, once the intermediate consumption needs of the beneficiary companies in the first instance by the cruise activity are triggered. A multiplier effect on the entire system, an indirect impact in terms of turnover, GVA (and wage income) and employment is thus generated ${ }^{6}$. We must also consider the induced impact of the consumption expenditure made by those workers whose jobs have been generated directly or indirectly due to cruise activity.

Using input-output methodology and the latest available Input-Output Table for Catalonia (for 2011) we estimated the indirect and induced contribution of cruise

\footnotetext{
6 The different concepts that compose the direct effect have been distributed among the 82 sectors in which the IO table of Catalonia is distributed. This procedure has allowed us to obtain a direct final demand vector and to be able to apply the input-output methodology to obtain the indirect effects.
} 
activities in the Port of Barcelona to the Catalan economy. We find that in 2014, cruise activity generated an additional turnover in Catalonia (indirect and induced) of $353.5 \mathrm{M}$ $€$ a GVA of 187.3 $\mathrm{M} €$ (of which $80.9 \mathrm{M} €$ were wage income) and 2,733 full-time equivalent jobs.

If we compare the results of the direct impact with the indirect and induced impact it can be concluded that for every $100 €$ of direct spending from cruise activity at the Port of Barcelona, $80 €$ in extra billing were generated in an indirect and induced way (multiplier coefficient 1.8 ). In turn, for every $100 €$ of GVA generated directly, an additional $83 €$ were generated in an indirect and induced manner (multiplier of 1.83), while for every 100 direct jobs, 68 were additionally generated in an indirect and induced way (multiplier of 1.68). These figures show the importance of the multiplier effects of cruise activity in the Port of Barcelona.

It should be noted that sectors with higher indirect and induced impact were not only tourism sectors (as with direct expenditure) but also include other sectors such as real estate, wholesale trade, construction, legal activities and the manufacture of food products (Figure 7). The importance of cruise activity is therefore noted as a new source of economic activity in areas that are not strictly "tourist" sectors.

[Figure 7 near here]

In this sense, it is very important to note that the diversification of the productive structure of the Catalan economy means that the size of the multiplier effects that remain in Catalonia become very relevant, as the estimated figures show.

\subsection{Estimated total impact of cruise activity}


If we consider jointly the direct, indirect and induced impact (Table 3), we can conclude that cruise activity in the Port of Barcelona generated a total turnover of $796 \mathrm{M} €$ (over 2.2 M $€$ daily) in 2014, a GVA of 413.2 M $€$ (of which $€ 197.6 \mathrm{M}$ were income wages) and a total of 6,759 full-time equivalent jobs in Catalonia.

[Table 3 near here]

We can see that, every $100 €$ of initial expenditure from cruise activity in the Port of Barcelona ended up generating, in total, $93 €$ of GVA (of which $45 €$ are income wages) in Catalonia. Moreover, for every million euros of initial expenditure, 15 jobs were created.

If the above figures are relativized by the number of cruise ships docked at the port, we can conclude that each cruise ship that stopped at the Port of Barcelona in 2014 generated, on average, in Catalonia, a 1 million $€$ turnover, contributed in more than half a million $€$ to GDP, and it was also responsible for 9 full-time jobs and 0.2 million $€$ of tax revenue.

The above results suggest, as mentioned, the impact that cruise activity has on the Catalan economy; however, we should also consider which part of the total impact remains in Barcelona city. While the full impact of territorialization is a very complex operation, it has been estimated that Barcelona would ultimately concentrate $75 \%$ of the total impact ${ }^{7}$. Thanks to the activity at the Cruise Port of Barcelona, almost $600 \mathrm{M} €(1.7$ $\mathrm{M} €$ a day) was generated, 313.4M $€ \mathrm{GVA}$, and 5,039 jobs were maintained in the municipality of Barcelona.

7 Two types of information were taken into account for this estimation: detailed information on the geographical origin of the suppliers of the companies and institutions that supplied goods and services to the shipping companies that operate in the Port of Barcelona; and the weight of Barcelona (in comparison to Catalonia) in terms of Social Security affiliates at sectoral level. 
Finally, Figure 8 shows the ten sectors with the greatest overall impact in terms of employment. It must be said that these ten sectors account for $75 \%$ of total jobs generated by cruise activity. This figure is much lower when compared with the sectoral concentration detected in the case of direct impact, where $98 \%$ of the direct jobs generated by cruise activity were concentrated in ten of the eighty-five sectors analyzed.

[Figure 8 near here]

Considering the sectoral breakdown, it is very important to emphasize again, and now with figures of global impact, that the benefits of activity at the Cruise Port of Barcelona not only affect the sectors commonly considered tourist-related, but extend throughout the economy. Taking, as an example, the results in terms of employment, seen as the 6,759 full-time jobs generated by cruise activity, 3,995 were in the five tourist branches by excellence (hotels, restaurants, retail, land transport and travel agencies and tour operators), that is $59 \%$ of the total, compared to the balance of $87 \%$ in the case of directly generated employment. By contrast, 2,764 jobs (41\% of the total) were in other sectors, most notably the areas of storage and related activities for transportation, food manufacturing, metallurgy, chemical industry, services, waste management and sanitation, or medical services. The impact on non-tourism sectors is even more important in terms of turnover. While tourism sectors ultimately received, in total, $339 \mathrm{M} €(42.6 \%$ of total turnover generated), this amount totaled $457 \mathrm{M} €$ in other non-tourist sectors (57.4\% of the total turnover generated).

4.4. Tax revenues generated by cruise activity 
Once the total impact was obtained, we quantified the tax revenues generated in terms of regional and state taxes. It was estimated that cruise activity in the Port of Barcelona generated a total revenue of 150.8 $\mathrm{M} €: 79.7 \mathrm{M} €$ corresponded to value added tax (VAT), 30.1 $\mathrm{M} €$ in the concept of the collection of personal income tax (income tax) and $41 \mathrm{M} €$ as corporate tax. Cruise activity generated additional income tax due to the collection of the tourist tax. The estimated amount of this tax was $844,643 €$ (3.2\% of the total collection of tourist tax in the province of Barcelona in 2014). This amount includes both the rate from cruise passengers in transit who stayed more than 12 hours in the city (estimated at $265,830 €$ and paid by shipping companies themselves), and the rate from those cruise passengers who spent the night in a tourist establishment (quantified as $578,813 €$ and paid by cruise passengers themselves to the establishment where they spent the night). 


\section{Other effects associated with cruise tourism}

It is important to briefly mention other effects, both positive and negative, that the literature identifies as derivatives of cruise tourism.

First of all, cruise passengers calling at the city, since the duration of their visit is limited (a few hours) if the visit was enjoyable, they are likely to decide to make a longer visit in the future (Penco and Di Vaio, 2014; Satta, et al. 2015). In the case of Barcelona, the surveys conducted among cruise passengers by Barcelona Tourism indicate that $90 \%$ say that they "certainly" or "probably" will revisit the city in the coming years, and $93.3 \%$ will "certainly" recommend the city to relatives, and friends.

Cruise activity acts as a clear catalyst that contributes to increasing investment in port infrastructure, revitalizing existing businesses and creating new activities (Bel and Fageda, 2008; Lindsay, 2011; Bond, 2015). The Port of Barcelona is a clear example of the above effects. The significant growth of the cruise segment has led, since 2000, to the implementation of significant investments in port infrastructure, both in adapting the existing terminals and creating new ones dedicated exclusively to cruise ships. There are also business (e.g. rental bicycles, musical performances and dance, etc.) that are offered during the stays of cruise passengers in the city. Moreover, it can be said that the relevance of the Port of Barcelona as a base port has generated a clear pull factor that has led to various shipping companies (and other companies in the sector) locating their headquarters in the city (e.g. Carnival and Royal Caribbean).

The literature also suggests the catalytic activity of cruises in the development of other means of transport, especially air traffic (Bel and Fageda, 2008; Lindsay, 2011). This is particularly evident in the case of the Port of Barcelona. Its importance as a base cruise port and the fact that $78 \%$ of cruise passengers boarding or disembarking at the port use 
aircraft as a means of transportation to or from the port have been crucial to the creation and maintenance of international routes that have their origin or destination in the Barcelona-El Prat Airport. Cruise traffic has therefore become a catalyst, especially for intercontinental routes from Barcelona Airport. There are several examples of airlines with a market-focused cruise vision, including, among others, Air Canada, American Airlines and Delta Air Lines for the North American market, and Emirates, Qatar Airways and Singapore Airlines for connections to Asia and Australia.

As evidence of this link between passengers on international flights and cruise passengers, Figure 9 shows the monthly series of cruise passengers who embarked in the Port of Barcelona and international passenger Barcelona-El Prat Airport since 2004. This seems to show the clear existence of a relationship between two variables (the correlation between the two variables is $75 \%$ ).

[Figure 9 near here]

This has been corroborated by applying cointegration techniques to these series, which has led to the conclusion that there really is a long-term relationship between the series of cruise passengers at the Port of Barcelona and passengers on international flights. It is noteworthy that these routes (whose origin is the transportation of cruise passengers) are subsequently also used by other types of passengers (especially, business travelers), a fact that increases the attraction of the city even further for foreign companies who decide to locate headquarters or offices in the city.

The literature also points to the existence of negative externalities resulting from the development of cruise tourism, however, especially related to the effects of agglomeration in the destination cities and the environment. 
Brida and Zapata (2010b), Pérez (2013) and Bonilla-Priego et al. (2014) highlight the "agglomeration effect" of cruise passengers when arriving simultaneously and in large numbers at certain points of the destination city and concentrating their visit in a few hours. This congestion is annoying for both other tourists and residents, and can even have a crowding-out effect on residents living in the historic centers of cities (Motta, 2014). In Barcelona, this concentration is also more evident since the cruise visits focus on certain parts of the city, including the old city, emblematic monuments and main shopping streets.

Many authors have warned of the effects of pollutant emissions from cruises (Dwyer and Forsyth, 1998; Butt, 2007; Howitt et al., 2010; Tzannatos, 2010, Bonilla-Priego et al., 2014). In recent years, however, there has also been efforts to relativize the environmentally harmful effects of cruise ships, showing how these emissions are lower than those produced by road traffic, industry and other economic sectors (Barcelona Regional, 2015, in the case of the Port of Barcelona). 


\section{Conclusions}

Cruise tourism is an increasingly important sector in the economy. In this article we have shown the methodology and the main figures of the local and regional economic impact generated by cruise activity. We have combined different issues: estimating the impact of the cruise port activity, presenting these impacts disaggregated at a sectoral level and carrying out a fieldwork based both on direct information provided by the different agents involved and also personal interviews with different institutions, companies and organizations linked to cruise activity and a specific representative survey addressed to cruise passengers.

In order to test and apply our methodology, we have quantified the regional economic impact of cruise tourism in the leading Mediterranean port, the Port of Barcelona, characterized by its strategic geographical position, its port infrastructure, its short, medium and long distance transport infrastructure, and the attractiveness of the city. We have shown that cruise activity in Barcelona has a very remarkable multiplier impact on the regional economy. From an initial direct expenditure of $442.5 \mathrm{M} €$, cruise activity in Port of Barcelona ultimately generated a total turnover of $796 \mathrm{M} €$ (over $2.2 \mathrm{M} €$ a day and a multiplier of 1.8) in Catalonia, a contribution to the GDP of 413.2 $\mathrm{M} €$ (of which $€ 197.6 \mathrm{M}$ were income wages), a total of 6,759 full-time equivalent jobs and $152 \mathrm{M} €$ of tax revenue. We have also found that all sectors, not just the traditional tourism-related sectors, profit from cruise activity. Proof of this is that, of the 6,759 jobs created in total, more than $40 \%(2,764)$ were concentrated in non-tourism sectors.

Cruise activity has also had a significant catalytic effect, providing connective flights to the airport and economic stability to other parts of the city, and creating new business 
opportunities. It also has an impact to the extent that there is a high probability of cruise visitors returning as tourists in the short to medium term.

Despite the significant economic benefits that cruise tourism generates over all the regional economy (as quantified in this article in the case of Barcelona), it is also important to mention the negative externalities arising from cruise activity. These externalities include the excessive congestion generated at certain points of tourist attraction in the city (especially by visits from cruise passengers in transit) and the environmental effects of emissions generated by cruise ships (some of them being very large ships). The methodology we have used does not take into account these negative effects and therefore our research has the limitation of not quantifying the negative externalities numerically. The use of a general equilibrium model could overcome these limitations, but its use requires a high level of information difficult to obtain in small areas such as ours. Future research could aim to quantify economically the negative effects of the pollution produced and the congestion generated in the affected areas. In the latter case, conducting a survey of residents and neighbors could be a good way of estimating the negative externalities produced by the agglomeration of cruise passengers. The reduction of negative effects associated with the cruise activity is a major challenge to making the development of the cruise tourism sector a sustainable activity. In this sense, the new legislative regulations adopted at European level, and improvements in the design and construction of ships and the increased use of cleaner fuels will contribute to this goal by reducing pollution. In turn, knowledge in advance about the stopover of cruise ships at the port should enable city managers to develop good overall planning that minimizes the effects of congestion on the host city. 


\section{References}

Barcelona City Council. 2015. "Survey Tourists 2014”. Tourism of Barcelona, Barcelona City Council.

Barcelona Regional. 2015. "Analysis of emissions and immissions contribution of the Port of Barcelona in 2013.” Barcelona Regional.

Barcelona Tourism. 2015. "Survey of Cruisers 2014”. Barcelona Tourism.

Bel, Germà and Xavier Fageda. 2008. "Getting There Fast: Globalization, Intercontinental Flights and Location of Headquarters." Journal of Economic Geography, 8 (4): 471-495.

Bond, M. 2015. “Global Connectivity”. Seatrade Cruise Review, Jun. 2015, p.47.

Bonilla-Priego, M.J., X. Font, and M.R. Pacheco-Olivares. 2014. "Corporate sustainability reporting index and baseline data for the cruise industry." Tourism Management 44: 149-160.

Braun, B.M., J.A. Dander, K.R. White. 2002. "The impact of the cruise industry on a region's economy: a case study of Port Canaveral, Florida". Tourism Economics, 8(3): 281-288. 
BREA (Business Research and Economic Advisors). 2007. "Economic contribution of cruise tourism in Mexico “, Vol. I, Impact Analysis. Caribbean Cruise Association of Florida. http://www.f-cca.com/downloads/mexico-study2.pdf

Brida, Juan Gabriel, and Sandra Zapata. 2010a.”Economic Impacts of Cruise Tourism: The Case of Costa Rica". Anatolia: An International Journal of Tourism and Hospitality Research 21(2): 322-338.

Brida, Juan Gabriel, and Sandra. Zapata. 2010b. "Cruise tourism: economic, sociocultural and environmental impacts". International Journal of Leisure and Tourism Marketing 1(3): 205-215.

Butt, Nickie. 2007. "The impact of cruise ship generated waste on home ports and ports of call: A study of Southampton”. Marine Policy 31: 591-598.

CERTeT Bocconi. 2015. "Socio-economic impact analysis of cruise activities of the port of Civitavecchia.” Ports of Rome and Lazio \& Business University Luigi Bocconi.

Chase, Gregory, and Ilan Alon. 2002. "Evaluating the economic impact of cruise tourism: a case study of Barbados." Anatolia: An International Journal of Tourism and Hospitality Research 13(1): 5-18. 
CLIA (Cruise Lines International Association) Europe. 2015. "The cruise industry. Contribution of Cruises Tourism to the Economies of Europe, 2015 Edition." CLIA Europe.

Del Corpo, B., U. Gasparino, E. Bellini and W. Malizia. 2008. 'Effects of tourism upon the economy of small and medium-sized European cities', Fundazione Eni Enrico Mattei (FEEM), Working Paper No. 44.

Dwyer, L., and P. Forsyth. 1998. "Economic significance of cruise tourism". Annals of Tourism Research 25(2): 393-415.

Dwyer, L.; P. Forsyth; T. Ho and R. Spurr. 2003a. "Estimating the regional and national economic impacts of tourism growth and special events". Journal on Hospitality and Tourism 2: 118-130.

Dwyer, L.; P. Forsyth and R. Spurr. 2003b. "Inter-industry effects of tourism growth: implications for destination managers". Tourism Economics 9: 117-132.

Dwyer, L; P. Forsyth and R. Spurr. 2004. "Evaluating tourism's economic effects: new and old approaches". Tourism Management 25: 307-317

Dwyer, L., P. Forsyth and R. Spurr. 2006. "Assessing the economic impacts of events: a computable general equilibrium approach". Journal of Travel Research 45: 59-66. 
Dwyer, L; P. Forsyth and R. Spurr, T. Ho. 2008. Tourism's Economic Contribution versus Economic Impact Assessment: Differing Roles for Satellite Accounts and Economic Modelling. In Woodside A;Martin D (ed.), Tourism Management. Analysis, Behaviour and Strategy, edn. 1, CABI, UK, pp. 459:469

Fletcher, J.E. 1989. "Input-output analysis and tourism impact studies". Annals of Tourism Research 16 (4): 514-529.

Forsyth, P., L. Dwyer and R. Spurr. 2014. “The impacts of Australia's departure tax: Tourism versus the economy?". Tourism Management 40: 126-136.

Garay, Luis Alonso, and Gemma Cànoves. 2012. "Cruism Tourism in Barcelona. From marginality to international leadership." Bulletin of the Association of Spanish Geographers 60: 253-271.

Gibson, Phillip, and Melissa Bentley. 2006. "A study of impacts - cruise tourism and the south west of England." Journal of Travel \& Tourism Marketing 20 (3/4).

Heng, T.M. and L. Low. 1990. "Economic impact of tourism in Singapore”. Annals of Tourism Research 17:246-269.

Howitt, Oliver J.A., Vincent G.N. Revol, Inga J. Smith, and Craig J. Rodger. 2010. “Carbon emissions from international cruise ship passengers' travel to and from New Zealand.“ Energy Policy 38: 2552-2560. 
Idescat. "Input-Output Table of Catalonia 2011.” Idescat. www.idescat.es (accesed june 1, 2015).

Lindsay, G. (2011), "Cities of the Sky”. The Wall Street Journal, February 26.

http://www.wsj.com/articles/SB10001424052748703408604576164703521850100

MedCruise. 2016. “MedCruise Yearbook 2013/2014.” Seatrade Cruise Review.

http://www.medcruise.com/ (accesed june 1, 2015).

Miller, Ronald E. and Peter D. Blair. 2009. "Input-Output Analysis: Foundations and Extensions", 2nd edition. Cambridge University Press.

Motta, P. 2014. "Cruises -the uncultural tourism endangering heritage worldwide".

Paper presented at VIII Annual Tourism Conference. Sustainability of Touristic Destiny Cities. Madeira, Portugal, April 4.

Murillo, Joaquín, Javier Romaní, and Jordi Suriñach. 2008. “The Impact of Heritage Tourism on an Urban Economy: The Case of Granada and the Alhambra". Tourism Economics 14(2): 361-376.

Murillo, Joaquín, Esther Vayá, Javier Romaní, and Jordi Suriñach. 2013. “How important to a city are tourists and daytrippers? The economic impact of tourism on the city of Barcelona". Tourism Economics 19(4): 897-917. 
Papadopoulou, G., and E. Sambracos. 2014. "Recent Evolution of Cruise Activities in European Ports of Embarkation: a Quantitative and Economic Approach.” Archives of Economic History 1 (XXVI): 7-26.

Penco, L.; and A., Di Vaio. 2014. "Monetary and non-monetary value creation in cruise port destinations: an empirical assessment." Maritime Policy \& Management 41(5): 501-513.

Pérez, L. 2013. “Assessing and managing cruise ship tourism in historic port cities: case study Charleston, South Carolina.” Phd diss., Columbia University.

Policy Research Corporation. 2009. "Tourist facilities in ports. The economic factor." European Commission, Directorate-General for Maritime Affairs and Fisheries.

Satta, G., F. Parola, L. Penco, and L. Persico. 2015 "Word of mouth and satisfaction in cruise port destinations". Tourism Geographies 17(1): 54-75.

Tzannatos, E. 2010. "Ship emissions and their externalities for the port of Piraeus". Atmospheric Environment 44: 400-407.

Wagner, J.E. 1997. "Estimating the economic impacts of tourism". Annals of Tourism Research 24: 592-608. 
World Tourism Organization. 2008. "Cruise tourism. Current Situation and Trends." Madrid: Published and printed by World Tourism Organization.

Zhou, D., J. F. Yanagida, U. Chakravorty and P. Leung. 1997 "Estimating economic impacts from tourism". Annals of Tourism Research 24 (1): 76-89. 